Pamiętnik Literacki 2018, 1, s. 185-198
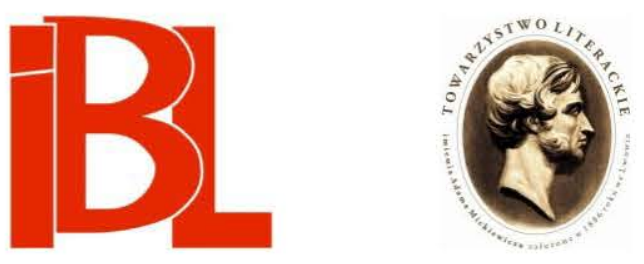

\title{
Opowiadanie zwizualizować pismem. \\ O pracy Oskara Kolberga nad tekstami ludowymi
}

Izabela Kotlarska 


\section{2. $\begin{array}{llllllllllllllllll} & \mathrm{M} & \mathrm{A} & \mathrm{T} & \mathrm{E} & \mathrm{R} & \mathrm{I} & \mathrm{A} & \mathrm{E} & \mathrm{Y} & \mathrm{I} & \mathrm{N} & \mathrm{O} & \mathrm{T} & \mathrm{A} & \mathrm{T} & \mathrm{K} & \mathrm{I}\end{array}$}

Pamiętnik Literacki CIX, 2018, z. 1, PL ISSN 0031-0514

DOI: $18318 / \mathrm{pl} .2018 .1 .10$

IZABELA KOTLARSKA Uniwersytet im. Adama Mickiewicza, Poznań

\section{OPOWIADANIE ZWIZUALIZOWAĆ PISMEM O PRACY OSKARA KOLBERGA NAD TEKSTAMI LUDOWYMI}

Zapisy utworów ludowych z XIX wieku są wielowarstwowym przekazem kulturowym, wartym namysłu i skupionej uwagi, przekraczających granice dyscyplin naukowych. Po Kalinowym lesie Czesława Hernasa, który przed kilkoma dekadami przywracał humanistyce poczucie istotności staropolskiego funkcjonowania folkloru, a także po badaniach Juliana Krzyżanowskiego niewiele mamy prac pozwalających zasypywać w folklorystyce polskiej przepaść między refleksją literaturoznawców i etnologów. Tymczasem dzięki dociekaniom tekstologicznym na temat stosowanych w XIX wieku zmiennych zasad zapisu stenograficznego, notacji form gwarowych i utrwalania gestyczno-sytuacyjnych składników przekazu, a następnie - aspektów performatywnych transliteracji i transkrypcji, można poczynić nowe spostrzeżenia, potrzebne do zbudowania pomostu między dwiema wspomnianymi dyscyplinami, a także ułatwiające włączanie elementów dziedzictwa w tradycję żywą.

Romantycy ogłaszali drukiem bajki ludowe ${ }^{1}$, które, jak wiadomo, bywały przez nich traktowane jako twórczość „polskiego Homera”, jednak wraz z rozwojem folklorystyki zwracano coraz większą uwagę na formę przekazywanych treści. Nie wystarczyło już pisać w „duchu ludu” - od folklorysty i jego zbioru wymagano tekstów odwzorowujących opowiadanie bajarza. Sposób ten jednak nie zyskał uznania wydawców pierwszej połowy XIX wieku. Nikt nie zdecydował się na przedstawienie takiego tekstu ${ }^{2}$, postrzegając go jako mało atrakcyjny dla potencjalnych

1 Bajki ludowe ukazywały się m.in. w drukach zwartych, z których najbardziej znane są zbiory: K. W. W ój c i c ki e go (1807-1879) Klechdy. Starożytne podania i powieści ludu polskiego i Rusi (1837), K. B a li ń s ki e go (1817-1864) Powieści ludu spisane z podań(1842), A. J. Gliń s k i e go (1817-1866) Bajarz polski (1853) czy S. W. B a rą cza (1814-1892) Bajki, fraszki, podania, przysłowia i pieśni na Rusi (1866). Pojawiały się też w czasopismach, takich jak m.in. „Tygodnik Literacki”, „Biblioteka Warszawska”, „Athenaeum”, „Przyjaciel Ludu”.

2 O problemie publikacji opowiadań ludowych pisał m.in. R. Z m or s ki, twórca wydanych w $1852 \mathrm{r}$. Podań i baśni ludu. Zob. R. W oj c i e c how s ki, Warszawskie. W zb.: Dzieje folklorystyki polskiej. Red. H. Ka pełús, J. Krzyża nowski. T. 1: 1800-1863-epoka przedkolbergowska. Wrocław 1970, s. 134: „We wstępie autor zaznaczył, że "obrabianiem, okrzesywaniem i dopełnianiem gminnej powieści podług własnych pojęć spisującego odbiera się zbiorowi wierzytelność", zaś z "niewolniczego stenografowania słów pierwszego lepszego wiejskiego opowiadacza powstaje książka zbyt jałowa dla czytelnictwa». Dlatego Zmorski wybrał drogę pośrednią”. 
czytelników. Metodę tę wprowadził dopiero Henryk Oskar Kolberg (1814-1890) w swojej pierwszej, pełnej monografii etnograficznej, w której bajki były elementem dokumentacji kultury ludu, a nie zbiorem literackim. Badacz jest uznawany za jednego z założycieli folklorystyki polskiej. Opisy regionów, zamieszkującego je ludu, obrzędów dorocznych i rodzinnych, teksty folkloru, w tym liczny zbiór bajek ludowych, stanowią zawartość opublikowanych dotąd 76 tomów (na 85 zaplanowanych) Dzieł wszystkich. Toczące się od lat sześćdziesiątych XX stulecia prace nad opublikowaniem zawartości archiwum XIX-wiecznego etnografa wraz z udostępnieniem wszystkich rękopisów w Wielkopolskiej Bibliotece Cyfrowej (w 2014 roku) wyznaczają nowy etap w badaniach spuścizny Kolberga.

Jednym z najtrudniejszych wyzwań, a zarazem niezbędną fazą działań każdego folklorysty jest transkrypcja treści istniejącej w formie ulotnej, audialnej na postać graficzną. Implikuje to bowiem konieczność umieszczenia dźwiękowej i somatycznej oralności w ramach wizualnego systemu komunikacji. Dzisiaj ułatwiaja nam to, przynajmniej pozornie, coraz bardziej zaawansowane technologie i wypracowane przez pokolenia metody badań. Jak jednak radzili sobie ci, którzy tę dyscyplinę dopiero tworzyli? Co miał na myśli etnograf, piszac: „podaję je [tj. bajki] w prostocie wysłowienia ludowego, nic nie ujmując ani dodając" (D 107) ? Roch Sulima, określając dzieło Kolberga jako „cmentarzysko oralności”, uwydatnił ową obrazową formułą typograficzny charakter tych przekazów i jego konsekwencje:

Od II połowy XVIII wieku, za sprawą typograficznego modelu „sztuki słowa”, kształtuje się, obowiązujący do naszych dni, model literatury i „literackości”. Oralny charakter folkloru, synkretyczna, wielotworzywowa i sytuacyjnie wyznaczona postać jego przekazów staje się zjawiskiem peryferyjnym, pozakanonicznym i pozasystemowym. [...] To właśnie kultura typograficzna, która zdominowała kulturę oralną i manuskryptową, przesuwa rozliczne praktyki słowa do folkloru i wyznacza jego pozycję, jego obraz i rolę, kształtuje też wiążące się z nim wyobrażenia społeczne (mityzację folkloru). Mamy zatem taki obraz folkloru, ale i literatury, jaki ukształtowała kultura typograficzna. Innego zresztą mieć nie możemy. Staram się pokazać, że ma to istotne konsekwencje dla dyskusji o folklorze i folklorystyce również dziś $[\ldots]^{4}$.

Liczne prace literaturoznawców, antropologów i filozofów zaowocowały szerokim spektrum badań nad oralnością. Przemysław Czapliński określa je jako rewolucyjne z powodu podejmowania $w$ ich ramach prób rekonstrukcji praw, jakie rządzą społeczeństwem żyjącym w kulturze oralnej, oraz analiz skupiających się na zmianach, jakie następują przez wprowadzenie w tych społeczeństwach pisma. Obydwa wspomniane zakresy studiów muszą się pojawić podczas rozpatrywania bajek ludowych zebranych przez Kolberga. W Polsce nad tym zagadnieniem pochylali się w różnym stopniu tacy badacze, jak Elżbieta Miller, Andrzej Mencwel, Grzegorz Godlewski, Jerzy Bartmiński i Stanisława Niebrzegowska-Bartmińska czy Marek Prejs ${ }^{5}$, zajmu-

3 Skrótem D odsyłam do wersji drukowanej: O. Ko l b e r g, Kujawy. Reedycja fotooffsetowa. Kraków 1962. Cz. 1, s. 107. Dzieła wszystkie. T. 3. Pierwodruk: Warszawa 1867. Natomiast wersję rękopiśmienną sygnalizuje skrót $\mathrm{R}=\mathrm{O}$. Kolberg, Kujawy. Rkps terenowy. Archiwum Polskiego Towarzystwa Ludoznawczego, teka 7, sygn. 1156. Liczby po skrótach wskazują stronice (w przypadku druku) lub karty (w przypadku rękopisu).

4 R. Suli m a, Folklorystyka jako antropologia słowa mówionego. „Literatura Ludowa” 2005, nr 4/5, s. 86.

5 E. Mille r, Bajka ludowa w zbiorach Kolberga. „Lud” t. 57 (1973). - A. M e n c w e 1, Wyobraźnia 
jący się szczególnie kwestią komunikacji społecznej, a w niej samym procesem, wykonawca oraz kontekstem kulturowym i sytuacyjnym tej komunikacji.

Podstawowe dla niniejszego szkicu pytanie dotyczy sposobu, w jaki relacja oralności i piśmienności kształtowała zebrane przez Kolberga bajki ludowe. Proponowaną dalej analizę opieram na rękopisach i druku siedmiu bajek ludowych z monografii Kujawy (tom 3 Dzieł wszystkich Oskara Kolberga; pierwodruk: 1867) ${ }^{6}$, która jest uznawana za pierwsze pełne opracowanie regionu wydane przez badacza. Analiza owa zostanie przeprowadzona zgodnie $z$ wnioskami wynikającymi ze studiów Waltera Jacksona Onga, Davida Richarda Olsona, Prejsa i innych uczonych zajmujących się relacją oralności i piśmienności, kultury i tekstu. Czerpać też będzie $\mathrm{z}$ wiedzy o warsztacie wielkiego etnografa i uwarunkowaniach kulturowych jego epoki. Wywody wzbogaci rekonstrukcja wywiadów Kolberga $z$ reprezentantami ludu oraz próba zrozumienia, czym (i dlaczego właśnie tym) kierował się on przy edycji usłyszanych tekstów.

\section{Badania terenowe}

Dla bajek zebranych przez Kolberga niezwykle znaczacy jest moment ich zapisu, dokonanego podczas badań terenowych. Etnograf w swoim szkicu autobiograficznym wypowiadał się o nich następująco:

podróże moje były obmyślane i uplanowane z góry, do przyjaciół i znajomych obywateli kraju w różnych mieszkających okolicach (lub do innych, za tychże listem rekomendacyjnym). Przybywszy tam, badałem najprzód i kaptowałem sobie ludzi dworskich, którzy, ośmieleni w służbie dworskiej, byli skorsi do pogawędki i śpiewu, a zrozumiawszy, o co rzecz chodzi, namawiali i sprowadzali innych ze wsi, iż za napitek i wynagrodzenie udawali się w tym celu do dworu lub pozwalali do swojej przychodzić chaty. Ponieważ wszędzie nader gościnnie byłem przyjmowany i konie do dalszej wycieczki miałem prawie zawsze na pogotowiu, przeto koszta takich podróży (ponoszone z oszczędzonych na zajęciach lub pracach moich pieniędzy) nie były zbyt wielkie, a czasami ograniczały się jedynie na datkach włościanom za pozyskane materiały ${ }^{7}$.

W ten sposób badacz eksplorował już Kujawy. W latach 1859-1869 prowadził zeszyt $z$ bieżącymi wydatkami ${ }^{8}$, w którym można odnaleźć notatki świadczące o tym,

antropologiczna. Próby i studia. Warszawa 2006. - G. G o d lew s ki, Stowo-pismo-sztuka słowa. Perspektywy antropologiczne. Wyd. 2, popr. Warszawa 2008. - J. Bartmiński, S. Niebrzegowska-Bartmińska, Tekstologia. Warszawa 2009. - M. Prejs, Oralność i mnemonika. Późny barok $w$ kulturze polskiej. Warszawa 2009.

$6 \quad$ Wstępne wnioski na temat relacji oralności i piśmienności w tekstach bajkowych zebranych przez O. Kolberga przedstawiłam w artykule Próba odtworzenia cech oralności $w$ drukowanych przez Kolberga tekstach bajkowych (w zb.: „Ja daję właśnie materiat...” O dziele Oskara Kolberga $w$ dwusetna rocznicę Jego urodzin. Red. E. A n t y b o r z e c. Poznań 2015), w którym opierałam się na tym samym materiale co tutaj. Ze zbioru Kujawy spośród 44 prozatorskich utworów fabularnych przeanalizowane zostały następujące: 1, 3, 4, 5, 8, 11, 13, oraz odpowiadające im 10 kart rękopisów zachowanych w archiwum Kolberga.

7 O. Kolberg, Szkic autobiografii. Bibl. PAN, rkps 2183, k. 68. Cyt. za: E. Mille row a, A. Sk rukw a, Oskar Kolberg (1814-1890). W zb.: Dzieje folklorystyki polskiej. T. 2: 1864-1918. Warszawa 1982, s. 31.

8 Fragment tego zeszytu został opublikowany w: D. P a w la k, „Kujawy” Oskara Kolberga. W: O. Ko lberg, Kujawy. Suplement do tomów 3-4. Zebrały, oprac. D. Pawlak, A. Skrukwa. Cz. 2. Poznań 2014, s. IX. Dzieła wszystkie. T. 72/II. 
że wynagradzał muzyków pieniędzmi za ich grę. Aby ułatwić sobie współpracę, przekonywał do siebie informatorów napitkiem i wsparciem finansowym, dzięki czemu zachęcano kolejnych ludzi ze wsi do odwiedzenia uczonego lub miejscowi zapraszali go do chat. $Z$ zachowanego itinerarium wiadomo też, że na tamtych terenach Kolberg przebywał u Biesiekierskich, Glińskich, Komeckich, Morzyckich i Sokołowskich ${ }^{9}$. Gdyby nie gościnność wielu rodzin, nie mógłby sobie pozwolić na badania terenowe i nie odwiedziłby niektórych regionów ${ }^{10}$, gdzie zebrał pokaźną ilość materiału. O tym, jak bardzo pomocni byli gospodarze etnografa, świadczy fragment listu Kolberga do Blizińskich (z 1883 roku):

Zdaje mi się, że jeszcze siedze przy Waszym długim stole bibliotecznym nastroszonym papierami i piszę, a pani [Pelagia, żona Józefa Blizińskiego] mi dyktuje lub objaśnia wyrażenia Halki, opowiadającej dziwy o czarach lub nucacej po raz dziesiąty swą sanocką piosenkę ${ }^{11}$.

Wiadomo też, że zarówno uczestniczyli oni w badaniach, jak i samodzielnie zbierali materiały. W ich listach do Kolberga można bowiem przeczytać:

Staram się wprawdzie zadowolić życzenia Pana i najszczegółowiej opisuję, co słyszę, a Pan wyrzuci lub zatrzyma, co uzna za potrzebne. Za autentyczność wszystkiego, co spisuję, ręczę, gdyż nie zadawalniam się tym, co słyszę od jednej osoby, lecz sprawdzam, czy ogół tak utrzymuje ${ }^{12}$.

Załączam Panu troszkę materiałów do etnografii, więcej zebrać nie mogłam, gdyż szewc, pomimo żem kilka razy do niego posyłała, nie chciał przyjść, popsuty widać szczodrymi Pana datkami, chociaż tentowałam go dobrą ze swej strony zapłatą, w którą, przypuszczam, nie ufał ${ }^{13}$.

Listy te potwierdzają jedynie współpracę z mieszkańcami później odwiedzanych regionów; nie wiadomo, czy tak samo wyglądała ona przy tworzeniu monografii Kujawy. Warto podkreślić, że korespondencja nie tylko podtrzymywała kontakty nawiązane $z$ właścicielami ziemskimi, ale też pozwalała na okazywanie przez Kolberga pamięci o informatorach, co było wyrazem grzeczności i wdzięczności oraz formą rekompensaty po przeprowadzonych wywiadach ${ }^{14}$.

Obraz badacza w terenie przedstawił Izydor Kopernicki ${ }^{15}$, który wspominał, że

9 Wykaz podróży Oskara Kolberga. W: Korespondencja Oskara Kolberga. Zebrał, oprac. M. Tu rc zy now i z zowa. Oprac. komentarzy, red. tomu A. Skrukwa, E. Krzyżaniak-Millerowa. Cz. 3: 1883-1890. Warszawa 1969, s. 705. Dzieła wszystkie. T. 66.

10 Mapa regionów znajduje się na stronie Instytutu im. O. Kolberga: http://www.oskarkolberg.pl/ pl-PL/Map (data dostępu: 4 III 2018).

11 O. Kolberg, list do J. Blizińskiego, z 28 IX 1883. W: Korespondencja Oskara Kolberga, cz. 3, s. 72 .

P. Blizińs ka, list do O. Kolberga, z 6 III 1884. W: jw., s. 125.

P. Blizińska, list do O. Kolberga, z 11 V 1885. W: jw., s. 250.

We współczesnej antropologii wiele uwagi poświęcono sytuacji wywiadu. S. Kvale (Prowadzenie wywiadów. Przeł. A. D zi u ba n. Warszawa 2010, s. 105) pisze: „Pod koniec wywiadu może pojawić się napięcie lub niepokój ze strony osoby badanej, która opowiadała otwarcie o swoich często osobistych i emocjonalnie angażujących doświadczeniach, a teraz zastanawia się nad tym, w jaki sposób wywiad zostanie wykorzystany. Niektórzy respondenci mają również uczucie pustki - przekazali nam bardzo dużo informacji na swój temat i nie otrzymali nic w zamian”. Owo uczucie może zostać zaspokojone, jeśli badacz podzieli się z respondentem swoimi doświadczeniami i historiami. W przypadku Kolberga pytania grzecznościowe i pozdrowienia przekazywane informatorom przez właścicieli majątku mogły odgrywać podobną rolę.

15 I. Kopernicki, Przedmowa. W: O. Kolberg, Chełmskie. Wyd. ... T. 2. Kraków 1891. 
podczas takich rozmów etnograf był wobec niechętnych i nieufnych ${ }^{16}$ przedstawicieli ludu spokojny, cierpliwy i uprzejmy. W ten sposób mógł od nich „wyciagnąc” jak najwięcej szczegółów, te zaś kazał sobie wiele razy powtarzać, by móc stworzyć wierny zapis. O skrupulatności w prowadzeniu notatek wspominał też sam w swoim liście ${ }^{17}$. Dzięki zachowanemu fragmentowi zaniechanej wersji wstępu do Pieśni ludu polskiego (1857), powstałej prawdopodobnie około roku 1849, wiadomo, jak przebiegał wywiad na początkowym etapie działalności Kolberga:

Po wyśpiewaniu melodyj nie zaniedbałem ze śpiewaka wybadać pochodzenie pieśni, jej początek, dawność i rozgałęzienie w okolicy. Częstokroć po dworach znajdowały się w służbie śpiewaczki z oddalonych stron będące, które tym samym wiele $z$ okolic rodzinnych i lat dawnych umiały śpiewów, lubo i w nowym siedlisku miejscowych pouczywszy się, którą to okoliczność zapytane przy wykonaniu wyraźnie wymieniały ${ }^{18}$.

Badacz skupiał się więc nie tylko na zapisie melodii i tekstu pieśni. Już w czasie pierwszych eksploracji określenie proweniencji geograficznej utworu było elementem podstawowym i najważniejszym w notatkach dokumentacyjnych. W suplemencie do tomów kujawskich Agata Skrukwa podkreśla jednak:

Analiza not lokalizacyjnych w rękopisach i w druku w połączeniu z innymi świadectwami nie daje [...] pewności, czy oznaczają one miejscowość, w której [etnograf] prowadził badania, czy też tę, z której pochodził wykonawca, przebywający w miejscu pobytu Kolberga ${ }^{19}$.

Źródła prawie nic nie mówią o sposobie pracy z opowiadaczami przed rokiem 1867. W Kujawach znajdujemy notatkę zamieszczoną przy opisie guseł, która świadczy jedynie o tym, że Kolberg próbował oddać żywą mowę i sytuację opowiadania:

Jak tylko diabły zoczyły onę czarownicę, tak dalej-że kusić nawiedzoną, że ta rzuciła się jak wściekła na przekupkę i pięściami tłuc ją poczęła do krwi, dopóki nie nadbiegli ludzie i nie rozbroili zwaśnionych, czego dopełnić $z$ wielka przyszło im trudnością. „Bo to diabeł w babie, serce wyrwie, i gardło (r)ozsadzi” (dodał opowiadający). [D 101]

Współczesnego czytelnika Kujaw może zastanawiać brak choćby najmniejszej wzmianki na temat informatorów, tak ważnych w dzisiejszych pracach związanych z literaturą ludową. Violetta Krawczyk-Wasilewska podkreśla, że w Polsce do połowy XX wieku twórczości ustnej nie przypisywano konkretnym artystom, lecz traktowano ją jako zróżnicowaną regionalnie reprezentację ogółu, grupy ${ }^{20}$. Nie wychodzono poza ten konstrukt myślowy mimo odmiennych, zaawansowanych pod

W swoim szkicu autobiograficznym O. Kolberg (Biblioteka PAU PAN w Krakowie, sygn. 2183, k. 68) notował: „boja[źliwi] chłopi, nieufni i podejrzliwi, na każdym kroku gotowi byli nieznajomych sobie apostołów chwytać i odstawiać do powiatu jako misariuszów narodowego rządu. Doświadczyłem tego w r. 1841, robiąc z Konopką wycieczkę do Czerska, gdzie oswobodzeni z ich rąk [...] jedynie byliśmy [po] rozumnej interwencji wójta miejscowej gminy".

17 Powstanie listu szacuje się na lata 1864-1865.

18 O. Kolber g, Pieśni ludu polskiego. Suplement do tomu 1. Zebrała, oprac. A. Skrukwa. Oprac. muzykologiczne M. Proch a s ka. Poznań 2003, s. 4. Dzieła wszystkie. T. 70.

19 Pawlak, op. cit., s. XI.

20 V. Krawczyk-W a silews ka, Indywidualny narrator ludowy. Polskie badania na tle międzynarodowym. „Literatura Ludowa” 1980, nr 4/6, s. 33. 
tym kątem studiów folklorystyki europejskiej. Badaczka wskazuje też na Kolberga jako prekursora w omawianej dziedzinie, ponieważ w pozostawionych przez niego rękopisach $z$ Krakowskiego znajdują się notatki o bajarkach. W rzeczywistości wszakże zapiski te są autorstwa Antoniny Konopczanki, która pomagała uczonemu.

Dzięki przytoczonym informacjom można zrekonstruować następującą sytuację wywiadu: przed Kolbergiem stoi lub siedzi chłop, który - poproszony o to - opowiada bajkę, mniej lub bardziej prawdopodobnie w gwarze kujawskiej. Należy (teoretycznie) wyłącznie do kultury oralnej, która kształtuje jego sposób myślenia, wynikający z językowego obrazu świata ${ }^{21}$. Siedząc przed tym chłopem, Kolberg - jako reprezentant kultury piśmiennej - notuje szybko to, co słyszy. Dodatkowa komplikacja pojawia się, gdy pismo staje się wzorem dla mowy ${ }^{22}$. Nadawca i odbiorca bajki posługiwali się odmiennymi modelami komunikacji oralnej, przez co ich dialog mógł być zakłócony. Uczony musiał odbierać przekazy różniące się od naturalnych dla niego (nie tylko ze względu na osadzenie w odmiennym modelu komunikacyjnym, ale też na różne pochodzenie stanowe i regionalne), odzwierciedlać je na papierze, a potem tak opracowywać, by były one zrozumiałe dla czytelników i spełniały wymogi stawiane przez ówczesnych folklorystów.

Tę zawiła sytuację podsumowuje w swoich rozważaniach na temat pracy etnologa Dan Sperber: „Wynikły opis jest właściwie tym, co etnolog wyselekcjonował $\mathrm{z}$ tego, co zrozumiał $\mathrm{z}$ treści przedstawianych mu przez informatorów $\mathrm{w}$ taki sposób, w jaki oni je rozumieli” ${ }^{23}$. Zgodnie $z$ tą myślą bajki ludowe Kolberga byłyby wielopoziomową rejestracją doświadczenia „niepiśmiennego” informatora i jego komunikatu oraz „piśmiennego" etnografa, starającego się ten komunikat uchwycić i potem tak przekazać, by jak najpełniej mógł go zrozumieć odbiorca jego monografii. Należy wszakże podkreślić, że jednoznaczny podział XIX-wiecznej rzeczywistości na oralną i piśmienna jest nieuprawniony - utrwalona przez Kolberga literatura ludowa stanowi rejestrację ustności zanikającej już wtedy społeczności przedindustrialnej. $Z$ dzisiejszej perspektywy przedstawiony przez autora Kujaw lud wolno prezentować zarówno jako społeczeństwo ustne, jak i piśmienne. Wpływ dworu, Kościoła i szkolnictwa był nieodłącznym elementem kultury ludowej XIX wieku, jednak Kolberg próbował gromadzić literaturę ludową, która, w jego pojęciu, zachowała się w stanie możliwie najmniej naruszonym. W roku 1875, wydając drukiem Krakowskie, etnograf wyjaśniał, jaki tekst uznaje za autentyczny, i tłumaczył, w jakich przypadkach oczyszcza przekazy ze zbędnych, jego zdaniem, naleciałości:

Do opisywanego tu chłopa pasuje charakterystyka sporządzona przez W. J. O n ga (Orality - Literacy Studies and the Unity of the Human Race. W: A Festschrift for Walter Ong. Ed. J. M. F ol ey. „Oral Tradition” 1987, nr 1. Cyt za: S. O b i r e k, Uskrzydlony umyst. Antropologia słowa Waltera Onga. Warszawa 2010, s. 181): „Sposób myślenia ludzi ze społeczności oralnych różni się od naszego nie dlatego, że oni są "dzicy" czy "niżsi", ale dlatego, że są tacy, jak tego wymaga język i oparty na nim sposób myślenia”.

22 Jak wyjaśnia D. R. Ols on (Papierowy świat. Pojęciowe i poznawcze implikacje pisania i czytania. Warszawa 2010, s. 156): „ponieważ pismo jest "czytane", zaczyna być traktowane jako model dla mowy; wszystko, co pismo przedstawia, staje się przedmiotem wiedzy lub świadomości posługującej się nim osoby". 
Przy spisywaniu staraliśmy się zachować język i sposób wyrażenia się ludowy, nie prostując ich, mimo widocznego braku porządku u opowiadacza; i tylko tam, gdzie opowiadający wyniósł ze szkoły pewną w dykcji przesadę i rozwlekłość, a nastrzępił mowę swą i skaził obcymi jej dodatkami na dworskim lub rządowym chlebie, pozwoliliśmy sobie oczyścić je $z$ tych narośli, nie nadwerężając autentyczności myśli i wyrażeń, i oddać w toku ludowej baśni odpowiednim²4.

$Z$ jednej strony, uczony starał się więc nie ingerować w rejestrowane podanie, z drugiej, widząc znaczące wpływy „pozaludowe” związane $z$ oświatą, oczyszczał z nich tekst. Część IV Krakowskiego wydał Kolberg osiem lat po części I Kujaw i wspomniane praktyki mogą być wynikiem jego doświadczenia w publikowaniu tekstów ludowych. W tomie Sanockie (tom 51 Dzieł wszystkich Oskara Kolberga, który ukazał się w 1973 roku, a oparty był na badaniach terenowych prowadzonych głównie w latach 1883-1885) znajduje się bajka opublikowana $z$ rękopisu Kolberga pt. Olbrzym jednooki. Towarzyszy jej przypis uczonego:

Baśń ta, przypominająca jednookiego Polyfema w Odysei, znana jest i u południowych Słowian (Ob. Dr Fr. S. Krauss, Sagen und Märchen der Südslaven. Leipzig 1883, s. 171: Der Waldmensch) ${ }^{25}$.

Tadeusz Skulina, autor opracowania tej części prac etnografa, dodał do tego przypisu komentarz:

Po słowie „Odysei” dopisał Kolberg zdanie, które następnie przekreślił: „Mogła [owa baśń] przez szkołę dostać się do ludu, lubo opowiadający ją starzec zapewniał, iż słyszał ją w młodości od ojca swego".

Widać więc, że Kolberg miał świadomość zmian w folklorze, jakie niósł ze sobą rozwój oświaty - w sposobach wyrażania siebie, w opowiadaniu, w rezygnacji z gwary czy przejmowaniu wątków znanych w literaturze wysokiej. Nie sposób jednak oszacować, w jakim stopniu wykształceni byli jego informatorzy, a w przypadku regionu kujawskiego - przez jego ówczesny podział administracyjny - pojawiają się szczególnie duże kłopoty z oszacowaniem szans na edukację tamtejszej ludności ${ }^{26}$.

Dodatkową sposobność styczności z kulturą wyższą mieszkańcy Kujaw mieli przez kontakty z dworami ziemiańskimi. Przykładu dostarczają Wspomnienia z przeszłości (1884) Antoniego Edwarda Odyńca, w których autor przywołuje postać

O. Kolb e rg, Krakowskie. Reedycja fotooffsetowa. Wrocław-Poznań 1962. Cz. 4, s. XII-XIII. Dzieła wszystkie. T. 8. Pierwodruk: Kraków 1875.

O. Kolb e rg, Sanockie-Krośnieńskie. Red. A. Skrukwa. Cz. 3. Oprac. T. Skulina. WrocławPoznań 1973, s. 162. Dzieła wszystkie. T. 51.

E. Anty b or ze c w swojej książce Monografie regionalne Oskara Kolberga. Założenia i realizacja (Poznań 2015, s. 171-172) nadmienia: „We wszystkich kolbergowskich charakterystykach Kujaw na pierwszy plan wysuwa się podział tego regionu na część przynależąca do Królestwa i część pruska, jednak bez wattpienia Kujawy to dla Kolberga kraina historyczna, a przede wszystkim region etnograficzny o wyraźnych cechach kulturowych mieszkającego tam ludu - Kujawiaków. [...] Ówczesne Kujawy to także teren zamieszkały przez dużą liczbę ludności niemieckiej [...]. Jednak poza kilkoma uwagami dotyczącymi osadników niemieckich i ich niewątpliwego wpływu na postępujący proces germanizacji, szczególnie tak zwanych Kujaw pruskich, monografia tego regionu to, jak już wspominano, monografia polskiego ludu kujawskiego z jego wyraźną odrębnością etnograficzną w stosunku do innych grup, swym zasięgiem obejmująca tereny powiatów: włocławskiego (podzielon[ego] później na włocławski i radziejowski) i inowrocławskiego". Warto podjąć studia nad typem kultury dworskiej tego regionu. 
Kornelii Ręczyńskiej. W swojej pamięci przechowywała ona Ksiegge tysiaca i jednej nocy, baśnie ludowe, niezliczone powieści czy legendy i historie biblijne. W zimowe dni zwoływała wszystkie dzieci (zarówno pastuszków, dziewczyny folwarczne, jak i potomstwo pańskie) i po odmówieniu modlitwy wszyscy zasiadali do skubania pierza lub przędzenia, słuchając przy tym opowieści Ręczyńskiej. Na rodzinna, głośną lekturę swoich tekstów mogli liczyć też autorzy literatury dziecięcej i młodzieżowej, której niezaprzeczalną prekursorką była w Polsce Klementyna z Tańskich Hoffmanowa ${ }^{27}$. Silnie moralizująca, o charakterze wychowawczym, literatura ta służyła za podstawę wykształcenia najmłodszych $z$ domów drobnoszlacheckich, a także mieszczańskich, których nie stać było na guwernera ${ }^{28}$. Obecność służby w codziennym życiu panów pozwalała jej na osłuchanie się nie tylko z muzyką graną na salonach, ale również z pojawiającymi się tam wypowiedziami, ideami, motywami literackimi, które $\mathrm{z}$ czasem w różnych konfiguracjach wchodziły do świata i jezzyka folkloru.

\section{Wpływ kontekstu na spisane bajki ludowe}

Dotychczasowe badania nad manuskryptami Kolberga pokazuja, w jaki sposób podstawowe prace edytorskie etnografa przynosiły mniej lub bardziej konieczne zmiany w tekście ${ }^{29}$. Jednak dodatkowym czynnikiem wpływającym na XIX-wieczne druki była cenzura: polityczna, stosowana przez władze zaborców, przede wszystkim Rosjan, oraz obyczajowa. Wydawca musiał liczyć się z oboma jej rodzajami. W archiwum Kolberga zachowały się zapisy polskich pieśni patriotycznych, jak również takich, których treść ośmieszała lub obrażała zaborców (np. pieśni na temat bitew z Rosjanami w czasach Batorego czy mówiące o polskim wojsku). W trakcie przygotowywania poszczególnych monografii uczony unikał publikacji takich utworów, świadom poważnych konsekwencji grożących ze strony cenzorów

27 Klementyna z Tańskich Hoff ma now a (1798-1845) była autorką wielu popularnych książek dla dzieci i młodzieży, jak m.in. Pamiątka po dobrej matce, czyli ostatnie jej rady dla córki (1819), Wiazanie Helenki. Ksią̇eczka dla matych dzieci uczących się czytać (1823), Ksiażeczka do modlitwy dla dzieci (1828). W twórczości pisarki były zawarte również wątki ludowe. Zob. A. Wit k ow s k a, R. Przyby ls ki, Romantyzm. Warszawa 1997, s. 627: „dbała Hoffmanowa o staranność realiów, zawsze rodzimych, z kręgu dostępnego poznaniu dziecka: wieś, Warszawa, jej domy i ulice, Ogród Saski itp. Umiejętnie dozowała także folklor ludowy, w komedyjce o weselu Marysi i Jasia zadziwiając nawet badaczy dobrą znajomością obrzędów ludowych”. Kolberg, redagując opisy historyczne miejscowości w swoich monografiach, np. Puław w Lubelskiem czy Iłży w Radomskiem, odwoływał się do prac Hoffmanowej publikowanych w „Rozrywkach dla Dzieci” m.in. w latach 1827-1828, jak np. Opis czwarty w kraju naszym przejażdżki Anielce Ł. przypisany („Rozrywki dla Dzieci” 1827, nr 45). W latach późniejszych korzystał z Opisów niektórych okolic Polski (w: Dzieła Klementyny $z$ Tańskich Hoffmanowej. Red. N. Ż mi ch ow ska. T. 5. Warszawa 1876).

28 Zob. Witkowska, Przybylski, op. cit., s. 138.

29 Millerowa i Skrukwa (op. cit., s. 97) wyliczają modyfikacje, jakie do tekstów wprowadzał badacz: „Poprawki i zmiany redakcyjne Kolberga zmierzały [...] do nadania opowieściom większej przejrzystości, czytelności, logiczności motywacji. Dopełniał zdania i fragmenty eliptyczne, dopowiadał wyjaśnienia niektórych wyrażeń gwarowych, uzupełniał człony gramatyczne lub ogniwa toku myśli, których brak oceniał jako szkodę dla klarowności fabuły. Eliminował lub poprawiał rażące nieporadności i zniekształcenia tekstu. Korygował wreszcie zwroty, wyrażenia i motywy nieprzyzwoite, [...] zastępując je mniej drastycznymi lub neutralnymi znaczeniowo [...]. 
rosyjskich ${ }^{30}$. Wśród analizowanych bajek nie ma podobnych treści (bohaterami bywają wojskowi, jednak charakter tych tekstów wyzuwa postacie $z$ narodowości), za to istnieją różnice pomiędzy rękopisami a drukiem wskazujące na dostosowywanie tekstu do panujacych wówczas obyczajów. Uczony niekiedy dodaje lub zmienia pewne fakty - widać to np. w bajce nr 1, O obrusiku, kuraszku i kijkach:

A on pożegnał staruszka i poszed. [R 3]

Podzi ę kował staruszkowi, pożegnał go i poszed [...]. [D 112 $]^{31}$

Wprowadzona zmiana wynika $z$ dobrych manier - bohater nie może zwyczajnie pożegnać staruszka, nie dziękując mu wcześniej, byłoby to niegrzeczne. Jeszcze bardziej widoczną modyfikacją są słowa dodane w zakończeniu bajki nr 3, O żotnierzu, żonie jego i wójtowej:

W tym czasie ona się [[wyjawiła]] \{przyznała\} kto była i wszystko opowiedziała. [[.]] i on z nią mieszkał na powrot a wojtowę stracono. [R 4]

W tym czasie óna sie przyznała, chto była, opowiedziała wszystko i królównę królowi odwiezła. A mąż prosił, żeby mu przebaczyła, i mieszkał z nią na powrót. Wójtowę stracono. [D 122]

W druku zła wójtowa i mąż okazują skruchę - ona posłusznie odwozi królewnę, a on przeprasza za brak wiary w prawdomówność swojej żony. Podobne różnice występuja pomiędzy dwiema wersjami tekstu bajki nr 13, O jeżu zaklętym:

Jedna kobita ni miała dzieci i idzie raz bez bór i napotkała jeża [...]. [...] I ona się z tego \{jeża\} cieszyła i cieszył się gospodarz. [R 4]

Jedna kobita ni miała dzieci $z$ m ęż e m. Idzie raz bez bór i napotkała jeża [...]. [...] I ona się z tego jeża cieszyła, i cieszył się gospodarz (j eji mąż). [D 142]

W dalszej części rękopisu pojawia się małżonek bohaterki, nazwany też ojcem jeża, jednak Kolberg uznał za stosowne w druku wcześniej podkreślić obecność tej postaci. Czy bez tej informacji wstęp bajki mógłby sugerować niepewny stan cywilny kobiety?

Zacytowane przykłady wskazują, że Kolberg w większości przypadków starał się uniknąc fragmentów problematycznych wedle ówczesnej obyczajowości. Wygładzenie tekstu dawało większą szansę na pozytywną recepcję monografii wśród czytelników oraz na potencjalny zarobek ze sprzedaży tomów. Jednak nie tylko

Druki zawierające teksty wspomnianego typu nie mogły być wydawane w Rosji, tj. także w Królestwie Polskim, ani przywożone na te tereny z zagranicy. Zob. m.in. J. Ko s t e c ki, M. Row i c ka, Granice wolności słowa $w$ zaborze rosyjskim $w$ latach 1865-1904. Wykaz publikacji polskojęzycznych zakwestionowanych oraz dopuszczonych do obiegu przez carska cenzurę zagraniczna. T. 1-3. Warszawa 2006.

31 Cytaty z rękopisów i druku zostały podane w transliteracji, bez ingerencji ortograficznej, ponieważ tylko w ten sposób można przedstawić niektóre znaczące różnice między wersjami. W celu podkreślenia niektórych z owych różnic w części cytatów zastosowano rozstrzelenie. Wszelkie glosy włączono do tekstu w nawiasie klamrowym. Gdy w rękopisie pojawiało się skreślenie lub miejsce nieczytelne, sygnalizowano to podwójnym nawiasem kwadratowym. Poprawki czy uzupełnienia oznaczono zaś pojedynczym nawiasem kwadratowym. Jeśli w druku występowała kursywa, została zachowana w transliterowanych cytatach. 
autor Kujaw był uzależniony od cenzury, także jego rozmówcy narzucali sobie autocenzurę - ze względu na słuchacza ${ }^{32}$. Wpływ na tekst miała okoliczność, przed kim opowiadano, ponieważ inaczej zwracano się do znanej sobie pani, a inaczej do zebranych na wieczornicy. Osoba badacza mogła onieśmielać, wzbudzać zainteresowanie czy niepewność. Nie jest to oczywiście reakcja wszechobecna i u każdego pojawiająca się równomiernie. $\mathrm{W}$ niektórych przypadkach niezastapione stały się pomocnice etnografa, które - choćby ze względu na swoją płeć - miały dostęp do informacji, jakie podczas rozmów Kolberga $z$ chłopkami nie zostałyby wspomniane ze względu na tabu społeczne.

Jak można uzupełnić to, co z komunikatu ustnego odarto w tekście pisanym? Warto pamiętać, że warstwa słowna bajki jest tylko małym procentem większej całości. Jak podkreśla Olson:

Każda ustna wypowiedź składa się $z$ tego, co powiedziane, oraz wskazówki co do sposobu jej traktowania (jako sąu, pytania, rozkazu, przysięgi itd.); pismo, utrwalając jedynie to, co powiedziane, reprezentuje tylko pierwszy składnik wypowiedzi. Ponieważ sposób jej traktowania pozostaje niedookreślony, staje się [...] głównym problemem w interpretacji tekstów pisanych, zaś problemem fundamentalnym - w ich konstruowaniu ${ }^{33}$.

W dalszych rozważaniach podjęta będzie próba uzupełnienia cech przekazu ustnego utraconych w piśmie. Bez wątpienia, gestyczność, somatyczność ${ }^{34}$ była integralną czesścią komunikatu oralnego, który odbierał etnograf, jednak podczas zapisu każdy tekst wypowiedziany ulega dekontekstualizacji, traci więc swoją „cielesność", a także - w dużym stopniu - czytelność. Kolberg, chcąc wypełnić ten brak, decydował się na wprowadzenie dodatków, które mogłyby świadczyć o gestach opowiadającego podczas opowiadania - jak w bajce nr 1:

Ten pozwólił a gdy obejrzał się, dziad go złapał i zbił okropnie [...]. [R 3]

Ten tyż pozwolił, a kdy obejrzał się, dziad go złapał za włosy i zbił okropnie [...]. [D 113]

W trakcie swojej przemowy narrator mógł chwycić się za głowę, pokazując, w jaki sposób dziad złapał jedną z postaci ${ }^{35}$. Podobna sytuacja zaistniała zapewne w przypadku bajki nr 4, O wężu zaklętym:

Przy obiedzie zapytał on, do której żony ma się pojść: do pierwszej czy do drugiej? i gdy mu odpowiedziano: że: do pierwszej - on też powiada: Oto jest. [R 4]

Przy obiedzie zapytuje się wszystkich panów: do chtóryj żony ma się pójść, czy do ty pirszyj, czy do ty drugij? i kdy wszyscy mu odpowiedzieli że: do pirwszyj-on wzion ja za rękę i stanoł przy ni i powiada do wszystkich: „Oto jest”. [D 123]

Kolejny przykład wynika z porównania rękopisu i druku bajki nr 5, O trzech braciach ptakach $i$ siostrze:

[[A]] Córka poszła po onę koszulę, a óni bracia ij się psocą. [R 365]

Córka poszła po onę koszulę, a óni bracia ij się psocą przed siennią. [D 123]

Zob. Millerowa, Skrukwa, op. cit., s. 97.

Ols o n, op. cit., s. 159.

Zob. Bartmiński, Ni ebrzegowska-Bartmińska, op. cit., s. 101-102.

Podobne formy ekspresji wykorzystują współcześni poznańscy opowiadacze miejscy. 
Dopisane przez badacza miejsce zdarzenia mogło zostać wskazane skinieniem ręki.

\section{Tekst a ton głosu}

Jak w zapisie odnaleźć cechę esencjalną mowy - jej dźwiękowość? ${ }^{36}$ Pytanie to odnosi się nie tylko do samego Kolberga; zmaga się $\mathrm{z}$ owym zagadnieniem każdy czytelnik i badacz rejestracji dokonanej przez etnografa:

Istnieje swoista organizacja fonetyczna całego ustnego (mówionego lub śpiewanego) t e k s t u, całej wypowiedzi (tempo, pauzy, akcenty „logiczne” wyróżniające rematy [...]), pewne zjawiska (np. intonacja pytajna) charakteryzują zdania, inne (np. akcent wyrazowy) odnoszą się do organizacji fonetycznej wyrazów. Ale wszystkie cechy fonetyczne wzajemnie się łączą i integrują na poziomie tekstowym, na którym dochodzi do harmonizowania trzech podstawowych cech - tonu, siły i iloczasu (na nich opierają się efekty odbierane przez ucho słuchacza jako melodia mowy, akcent i długość trwania), oraz czterech dodatkowych, jakimi są tempo, pauza, rytm i - najbardziej zindywidualizowana - barwa. Sztuka recytacji i sugestywnego mówienia polega na ich łączeniu i dostosowywaniu do stylu i intencji przekazu $^{37}$.

Przekaz graficzny może więc oddać tylko pewne cechy dźwiękowości, ale dzięki niektórym zabiegom Kolberga, a także figurom stylistycznym naturalnie używanym w narracjach, w analizowanych bajkach da się odnaleźć jej sygnały.

Odzwierciedlenie fonetyczne słownictwa gwarowego na poziomie leksyki jest najbardziej widoczną realizacją jego dźwiękowej postaci. Kolberg podkreślał rangę gwary już w swoim programie, opublikowanym na łamach „Biblioteki Warszawskiej” w 1865 roku. Później rozwijał gwaroznawcze zainteresowania, o czym świadczy np. artykuł Rzecz o mowie ludu wielkopolskiego ${ }^{38}$ czy Instrukcja do badania właściwości ludowych ${ }^{39}$. Uczony starał się zapisywać tekst fonetycznie ${ }^{40}$, choć często formy gwarowe przeplatał $\mathrm{z}$ językiem swojego środowiska. $Z$ pewnością czasem trudno było etnografowi „przestawić się” ze swojego mechanicznego, poprawnego zapisu na odmienny, pozornie błędny. Wskazują na to liczne różnice pomiędzy

Bartmiński i Niebrzegowska-Bartmińska (op. cit., s. 99) podkreślają: „Dźwięk jest nośnikiem tekstu ustnego, jego substancjalnym tworzywem tak, jak grafia jest takim nośnikiem w wypadku tekstu pisanego. [...] Nadawca i odbiorca słowa mówionego usytuowani są wewnątrz dźwięków, dźwięki otaczają ich z każdej strony. Inaczej jest w wypadku pisma, które przez odbiór wzrokowy sytuuje obydwu na zewnątrz tworzywa. $Z$ tym wiąże się także funkcja pisma i dźwięków mowy: pismo wyodrębnia, różnicuje, podkreśla odrębność, zaś żywe słowo - wypowiadane dzięki naturalnym artykulatorom i odbierane uchem, nastawione jest na łączenie i harmonizowanie. Okalające działanie dźwięku, a raczej całego pola dźwiękowego, które otacza człowieka, a nie tylko rozciaga się przed nim, wpływa także na odbiór otaczającego świata”.

Ibidem, s. 100.

38 Artykuł został przedrukowany w: O. Kolb e r g, Studia, rozprawy i artykuty. Oprac., red. E. Miller, A. Skrukwa. Wstęp J. Burszta, M. Gruchmanowa, A. Posern-Zieliński. Wrocław-Poznań 1971. Dzieła wszystkie. T. 63. Pierwodruk: „Zbiór Wiadomości do Antropologii Krajowej" t. 1 (1877).

Zob. Korespondencja Oskara Kolberga, cz. 3, s. 772-776.

40 Na potrzeby monografii Kolberg stworzył własny system zapisu gwary, który zbliżony jest do współczesnego. Zob. M. G r u c h m a n o w a, Oskar Kolberg jako gwaroznawca. „Polska Akademia Umiejętności w Służbie Nauki” 1998, nr 1. 
manuskryptami terenowymi a drukiem, odnotowane przez badaczki spuścizny Kolberga:

W tekstach drukowanych widoczne są formy gwarowe, które w rękopisie mają postać poprawnościową, np. w druku „powieda”, „oświarczył”, „umarty”, [...], w rkp. „powiedział”, „oświadczył”, „umarły” [...]. [...] Wielokrotnie w rękopisach widać jednak zapisy form gwarowych starannie powtórzone w druku, np. „jenny” (inny), „królówne” (królewnę), „czérznie” (ciernie), „ózświeć” (rozświeć, poświeć) [...]. W rękopisach zauważamy też sporadycznie zapis głosek pośrednich lub wariantów wymowy podwojo-

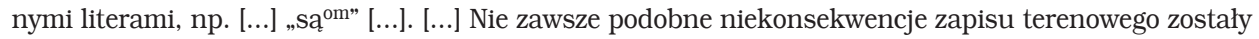
skorygowane, nie mamy jednak pewności, czy sytuacje takie oddają niepewność Kolberga co do brzmienia słowa, czy wahania wymowy osoby opowiadającej bajkę, czy wreszcie błąd zapisu lub druku ${ }^{41}$.

W manuskrypcie bajki nr 8, O czarnoksiężniku i trzech dziewicach, występuje czasownik „miauczeć”, na którego realizację gwarową Kolberg zwrócił szczególną uwagę:

wychodzi kocisko i miańczy i miańczy [nad „a” napisane „o” - I. K.] [...]. [R 3]

wychodzi kocisko i miończy, i miończy (miałczy) [...]. [D 131]

Etnograf nie był pewien, co słyszy, nie wiedział, w jaki sposób ma to słowo zapisać, dlatego wynotował dwie możliwości. W druku zdecydował się na „miończy”, bliższe drugiej wersji z manuskryptu. Ten wyraz musiał być dla Kolberga wyjątkowy, tak jak inne przez niego podkreślone, wynotowane przez Danutę Pawlak: „Podkreślił np. słowa "skarupka", "pastuż", "chrostę", "miańczy i miańczy" (tj. miauczy i miauczy), "pierścianek" $z$ jeszcze raz nadpisanym "a", "móma" (mamy)" 42 . Według badaczki takie zaakcentowanie służyło zaznaczeniu form użytych przez narratora.

Przytoczony fragment bajki nr 8 ukazuje też zachowane powtórzenie, jakże typowe dla oralnego wykonania. Prócz pełnienia funkcji mnemotechnicznych oraz ułatwiania komunikacji ${ }^{43}$ repetycja w drukowanych bajkach Kolberga odgrywa jeszcze rolę semantyczną i estetyczną. Etnograf w swojej edycji wprowadza powtórzenie słów sugerujące nasilenie czynności nimi oznaczonych - np. w bajce $\mathrm{nr} 1$ :

I szed bardzo daleko [...]. [R 3]

I szed, i s zed bardzo daleko [...]. [D 113]

W wersji drukowanej uwzględniona zostaje tym samym istotna cecha opowiadania. Powtórzenie, dzięki swoim cechom intonacyjnym w prozodii, wskazuje czytelnikowi możliwy sposób zrealizowania tekstu - głosem lub w wyobraźni ${ }^{44}$.

Ostatnim sposobem kodowania dźwiękowości jest zastosowana przez etnografa interpunkcja. W XIX-wiecznej polszczyźnie następują zmiany ${ }^{45} \mathrm{w}$ przestankowaniu -

41 Pawlak, op. cit., s. LII-LIII.

42 Ibidem.

43 Powtórzenie pozwalało słuchającym być na bieżąco z płynącą historią, a opowiadającemu dawało czas na namysł, co mówić dalej.

44 Autorką opracowania podstawowego dla omawianego tematu, Prozodia języka polskiego (Kraków 1947), była M. Dłu s ka. Książkę wznowiło PWN w 1976 roku.

45 Do najważniejszych zapisów prób reform ortografii polskiej w XIX w. należą dzieła: Rozprawy i wnioski o ortografii polskiej ogłoszone przez Towarzystwo Przyjaciół Nauk w 1827 r., następnie 
z modelu retoryczno-intonacyjnego przechodzono wtedy do interpunkcji logiczno-składniowej ${ }^{46}$. W swoim wstępie do Kujaw Kolberg używa interpunkcji inaczej niż w Powieściach, co wynika m.in. z funkcji, jakie obie te części pełnia w monografii. $\mathrm{W}$ tekście autorskim badacza sposób przestankowania jest zgodny $\mathrm{z}$ uzusem i z zaleceniami dla obiegu piśmiennego (egzekwowanymi w szkołach i powielanymi w drukach). Natomiast interpunkcja zastosowana w partiach fabularnych prezentuje się w druku już odmiennie: wyraźnie spostrzegamy pozorny chaos, który jest związany z wprowadzeniem wersji retoryczno-intonacyjnej, wynikającej w bajkach $z$ próby zachowania ustnego charakteru wypowiedzi - wyrażonego m.in. wyliczeniowym układem tekstu, pozostawionymi powtórzeniami, formulicznością, eliptycznością, przewagą zdań współrzędnych. Ten zabieg pozwalał na wierniejsze odtworzenie strumienia mowy, a na tym badaczowi zależało. Druk ludowych bajek kujawskich przypomina dzisiejsze transkrypcje nagrań terenowych $z$ realizacji pierwotnej głosowej, a w mniejszym stopniu projektuje głosowe wykonanie dla czytelników ${ }^{47}$.

Zaprezentowane analizy są cząstkowe i ograniczone do jednej monografii Kolberga, można wszakże na ich podstawie pokusić się o ostrożne uogólnienie. Jego trzonem jest przekonanie, że zebrane przez XIX-wiecznego etnografa bajki ludowe sa wielowymiarowym, zakodowanym zapisem niepowtarzalnego wykonania zrealizowanego przez informatora ludowego. $Z$ szerokich badań nad dziełem Kolberga wiadomo, że mimo stosowanych założeń i metod nie zawsze postępował on konsekwentnie przy edycji swoich zbiorów. $Z$ jeszcze mniejszą dozą pewności można o tych założeniach mówić w przypadku Kujaw, które stanowią pierwszą pełną monografię regionalna tego autora - swe metody bardziej w niej on kształtował, niż wprowadzał w życie tak, jak w monografiach późniejszych. Można wszakże dostrzec pewne tendencje, które, choć nie zawsze, to jednak wyłaniają się w wyniku analiz porównawczych. Etnograf zwracał szczególną uwagę na rytmikę i melodię słów. Używał znaków interpunkcyjnych jako sygnałów różnej długości pauz i, ewentualnie, wysokości tonu. Stosował konwencje poetyckie wspomagające odzwierciedlenie prozodyjnego kształtu tekstu ustnego, co pomagało zaprezentować szerzej jego dźwiękowość. Wyzwaniem dla badacza stała się próba fonetycznego zapisu kujawskiej gwary, która uznawał on za jedną z ważniejszych cech regionu. Kolberg nie pomijał też informacji pojawiających się poza brzmieniową warstwą przekazu. Co zaobserwował w mowie ciała, przekuwał w słowa, łącząc w ten sposób oraturę i literaturę w (nie zawsze) spójny przekaz.

Rozprawy i wnioski o ortografii polskiej przedstawione przez Deputację Ortograficzną w 1830 r., później Gramatyka języka polskiego A. Kryńskiego, która ukazała się w 1877 r., oraz zlecony przez ministra wyznań religijnych i oświecenia publicznego w $1891 \mathrm{r}$. Projekt ortografii polskiej $w$ podręcznikach szkolnych. Więcej na ten temat - zob. E. P ol a ń s ki, Reformy ortografii polskiej-wczoraj, dziś, jutro. „Biuletyn Polskiego Towarzystwa Językoznawczego” t. 60 (2004).

Zob. K. Gó r s ki, Tekstologia i edytorstwo dzieł literackich. Warszawa 1975, s. 236.

47 Przygotowanie tekstu z myślą o głośnej lekturze było w XIX w. praktykowane nierzadko; można też zauważyć znaczenie (potencjalnego) wygłoszenia dla organizacji tekstu pisanego. O problemach związanych z edycją i interpretacją XIX-wiecznych tekstów artystycznych zob. np. E. N o wi c ka, Czytać i słyszeć. (O tekście autografu „Księdza Marka” Juliusza Słowackiego). W zb.: Juliusz Stowacki-poeta europejski. Red. M. Ci eśla-Korytows ka, W. Szturc, A. Zi ołowicz. Kraków 2000 . 
Abstract

IZABELA KOTLARSKA Adam Mickiewicz University, Poznań

\section{VISUALISING STORY AS WRITING ON OSKAR KOLBERG'S WORK ON FOLK TEXTS}

The subject of the paper are folk tales presented here as a complex and multilayer cultural palimpsest which combines orality and textuality, folk creation, and high culture conventions demonstrated in a work of a folklorist - collector and editor. The issue of diverse understanding of fidelity of recording the folklore texts in the $19^{\text {th }} \mathrm{c}$. is discussed here - as based on the analyses of field records the effects of spoken words transcriptions are reconstructed. The paper also accounts for many various performative aspects (e.g. the character of situation, tone of voice and gestures), then it the specificity of the work of folklorist-editor who wanted to most generously offer the reader what he saw and heard. The article's goal is finding the context of Kolberg's fables creation, namely all that accompanies telling the stories but lies outside the word. 